\title{
Russian agriculture: regional specialization is increasing (case study: meat poultry sector)
}

\author{
Olga Kostenko ${ }^{1, *}$ \\ ${ }^{1}$ Vyatka State Agricultural Academy, 610017, Oktyabrsky Avenue, 133, Kirov, Russia
}

\begin{abstract}
This paper presents the results of studies of regional specialization and territorial concentration in agriculture. The poultry meat branch was chosen as the object of research. This is one of the most dynamically developing sectors of agriculture in Russia. Modified localization coefficients were used as a method for detecting the territorial concentration of the sector. The analysis showed that more than half of the output of poultry meat products was concentrated in the territory of 12 regions of Russia. The largest localization of poultry farming is in the center of the European part of the country, near large cities. The level of territorial concentration of the poultry meat sector increased significantly over the period of 2004-2017. The localization coefficients of the regions that specialize in poultry meat production have more than doubled. There is an increase in "polarity" in the specialization of regions. Some regions continue to increase the production of poultry meat, the level of regional specialization is growing. In other regions, poultry production is declining. Taking the poultry meat sector as a case study, it has been shown that the processes of regional specialization and territorial localization are increasing in Russian agriculture.
\end{abstract}

\section{Introduction}

For more than 10 years, Russian agriculture has been growing. The level of self-sufficiency in Russia for basic foods has reached 90-96\% (meat, grain, etc.). Large agricultural holdings focus their strategies on increasing product exports. These results have been achieved largely by means of government programs for the development of agriculture.

In the context of growth in the industry, structural changes are occurring, including in the regional aspect. The institutional structure of agriculture is changing. Some regions are focusing on the development of large-scale production. In other regions, farmers and households predominate. In general, the share of large farms and holdings in the structure of production output is increasing throughout the country [1].

The agrarian specialization of Russian regions is also changing. The research [2] showed that for the period of 2004-2014, the central regions of Russia abandoned commercial production of rye. The high localization of rye is preserved only in the Bryansk Region, bordering Belarus. During the same period, the regions of the Volga Federal

* Corresponding author: kostenko_ov@,vgsha.info 
District retained their specialization in the production of rye, the level of its territorial localization (concentration) even increased.

Studies of spatial distribution and regional specialization traditionally belong to the basic sections of economic science. The theoretical basis of research in this area is initially formed by the location theory, which later included such academic directions as the concept of new economic geography, the theory of clusters, and the concept of smart specialization $[3,4]$. Research results are in demand and are used to develop the governmental economic policy [5].

Typically, research in the area of regional specialization covers a period of 10 years or more. For Russia, it is important to compare with developing economies. In China, in the period from 2004 to 2015 , the indicators of industrial concentration, regional specialization, and clustering increased [6]. Structural transformations, including an increase in the level of specialization, are taking place in the agriculture of India [7]. Geographic proximity promotes economic growth and development in agri-food systems [8-10]. At the same time, the growth of regional specialization does not always bring only positive effects [11].

Russian research in this area is mostly carried out taking the industrial sector as a case study [12-14], including in the field of export specialization of regions [15]. Kutsenko and Eferin [16] found that the largest transformations occurred in the so-called "semiperipheral" regions, and the greatest growth in specialization occurred in the foodprocessing industries.

Many researchers emphasize the relevance of studies on the spatial distribution and evolution of regional specializations, and at the same time point to their insufficiency [12, 16]. There are practically no such studies in agriculture and food industries.

The poultry meat industry was chosen as the object of research. This is one of the most dynamically developing sectors of agriculture in Russia. Poultry meat production reached 4.9 million tons in carcass weight in 2017 , which is about $4 \%$ of the global market. The share of poultry meat in the meat balance of Russia during this period has increased greatly - from 18\% (1990) to 48\% (2019).

The aim of this study is to analyze the territorial distribution of poultry meat farming in Russia and identify trends in the change in regional specialization.

\section{Materials and Methods}

The theoretical and methodological basis is made up of works on the location theory and the theory of clusters. Localization coefficients were used as a method for detecting the territorial concentration of the industry.

When choosing a method for calculating the localization coefficients, the author took into account the specific features of agricultural statistics. It was impossible to apply the classical formula of the localization coefficient, which uses indicators of the average annual number of employees only. However, statistics of agricultural sectors have indicators of agricultural production in kind. This provides a good opportunity to analyze the territorial distribution of industries based on the method of modified localization coefficients. The modified localization coefficients were used, which were calculated for agricultural production in physical terms (production of poultry meat, live weight) in proportion to the average annual number of employees (formula 1).

$$
\text { Local }=\frac{P V_{i} \div N E_{i}}{P V \div N E}
$$

where: Local - localization coefficients;

$P V_{i}$ - production of poultry meat (live weight) in the $i$-th region; 
$N E_{i}$ - average annual number of employees in the $i$-th region;

$P V$ - production of poultry meat (live weight) in Russia;

$N E$ - average annual number of employees in Russia.

A high threshold of localization coefficient equaling 2.0 was selected. The data used for calculations has been taken from the official website of the Federal State Statistics Service of Russia.

\section{Results}

\subsection{Russian poultry meat sector's trends}

Poultry farming is one of the sectors of agriculture in Russia, which not only restored but also increased the volume of production (3.35 times in 2017 compared to 1990) (Fig.1).

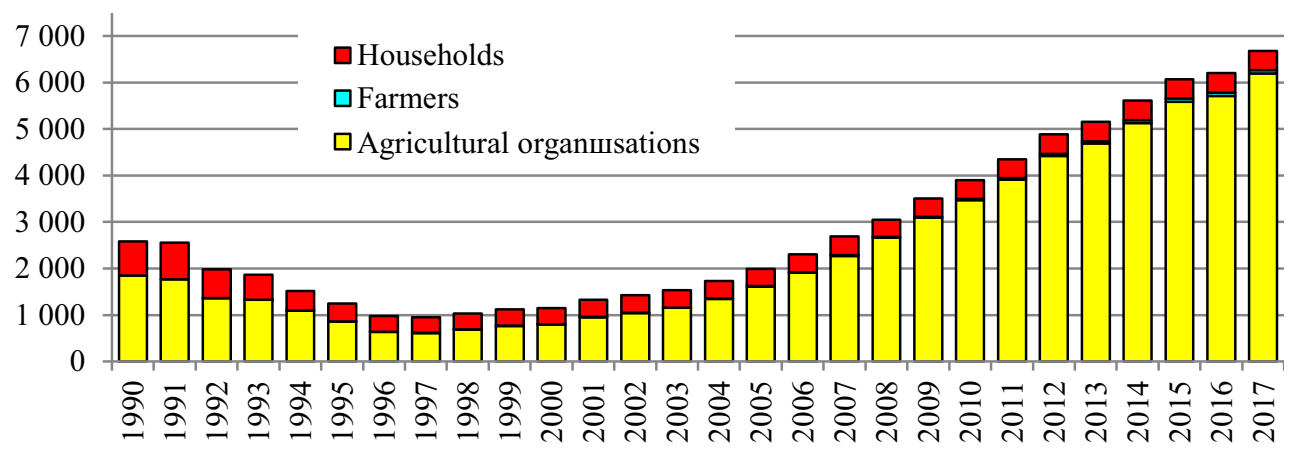

Fig. 1. Poultry meat production (live weight) in Russia, by farm category (thousand tons). Source: compiled by the author based on data from https://fedstat.ru/.

During the growth stage in the sector, there have been significant changes in the structure of the producers. Agricultural organizations produce the majority of poultry meat, in 2017 their share reached $93 \%$ (in 1990, being only 72\%). Personal subsidiary plots of the population produce only $6 \%$ of the output, while in 1990 this figure was $28 \%$. Small farms provide only $1 \%$ of poultry meat. Considering this circumstance, further in the analysis the data only for the segment of agricultural organizations will be used.

Another feature is that large vertically integrated agricultural holdings dominate in the poultry sector in Russia. They are estimated to account for over $60 \%$ of the sectoral output. The situation is similar in pig farming.

\subsection{Changes in the territorial location of the sector}

Changes in the territorial distribution of the sector that occurred in the period from 2004 to 2017 are shown in Fig. 2 and Fig. 3. The results obtained indicate that the territorial concentration in the poultry meat sector is increasing at a significant rate. 


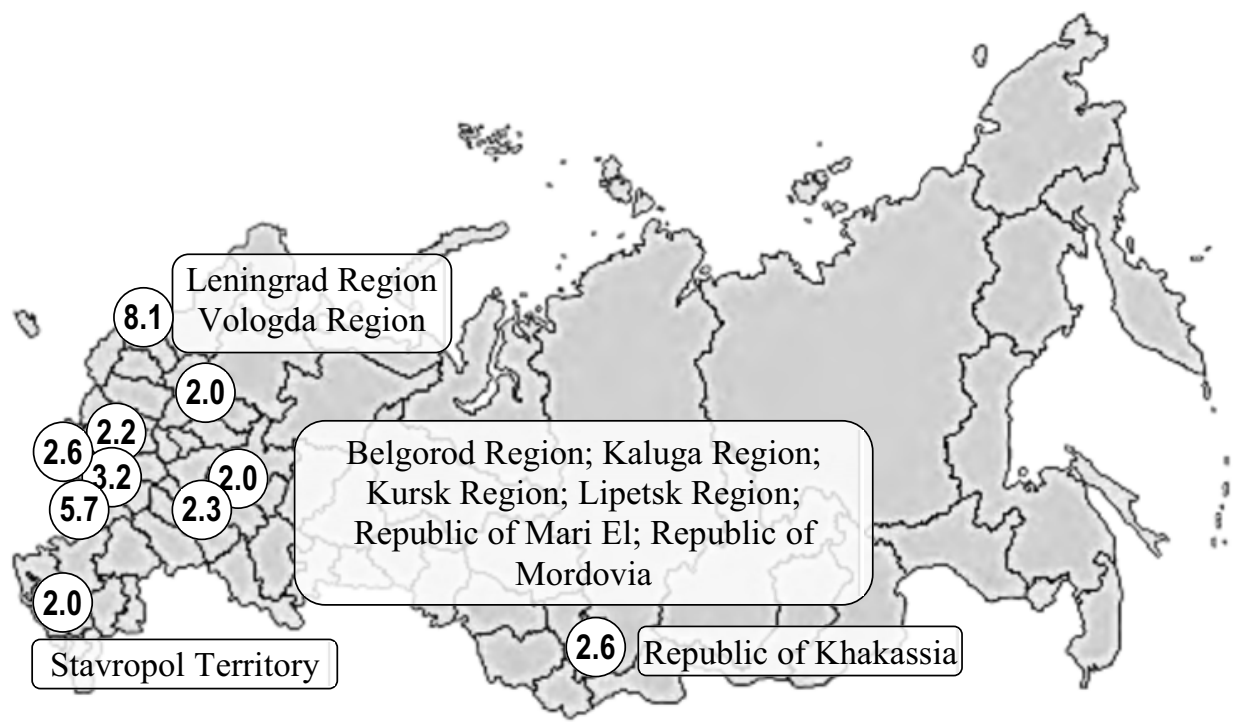

Fig. 2. Map 2004: Russian regions with localization coefficients above 2.0 (were calculated according to the indicator "poultry growths (live weight), in agricultural organizations", in proportion to the average annual number of employees). Source: compiled by the author based on data from https://fedstat.ru/.

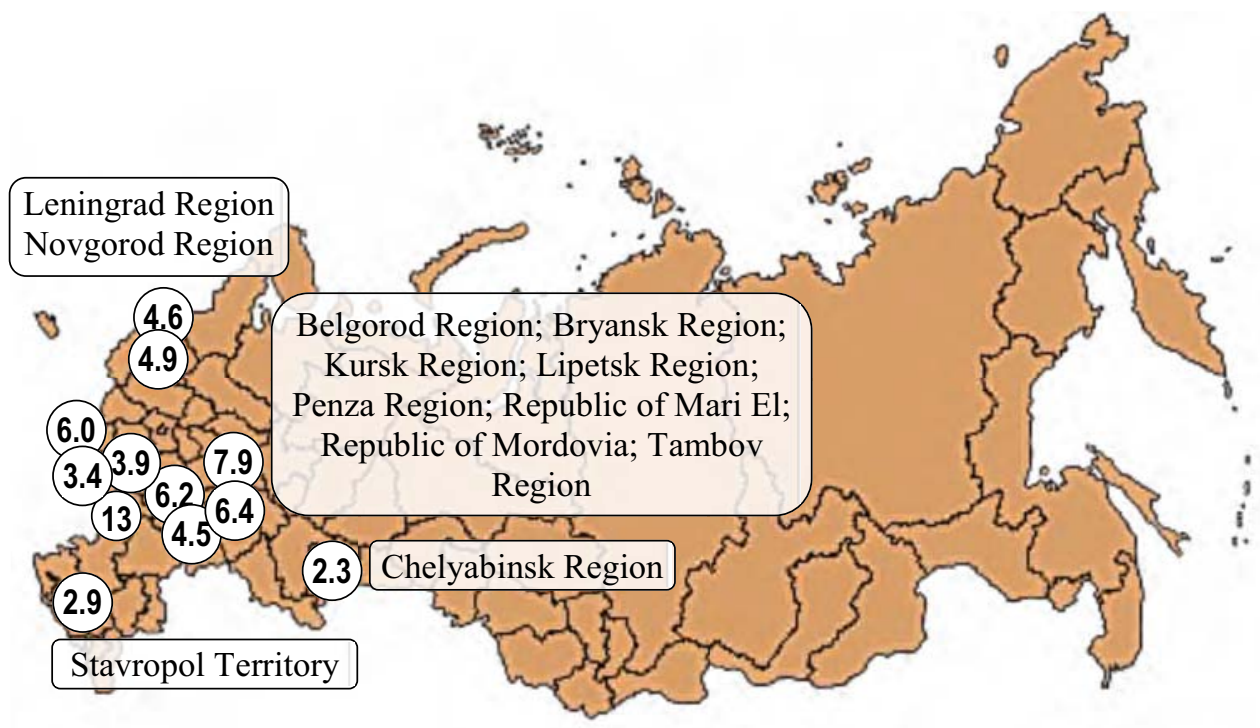

Fig. 3. Map 2017: Russian regions with localization coefficients above 2.0 (were calculated according to the indicator "poultry growths (live weight), in agricultural organizations", in proportion to the average annual number of employees). Source: compiled by the author based on data from https://fedstat.ru/

The largest concentration in the meat pig sector is located in the central regions of the European part of Russia. The second largest territory is the regions of the North-West of the country. The analysis revealed two trends.

First, the size of the territories where poultry meat is produced for export is increasing. Bryansk, Penza, and Tambov have been added to the central group during 13 years. In the 
North-West, Novgorod has become one of the regions with a high specialization in poultry meat farming.

Second, the level of specialization of these regions has greatly increased. The only exception is the Leningrad Region, where the localization coefficient dropped from 8.1 to 4.6. However, it should be noted that the region did not reduce, but on the contrary, increased the volume of poultry meat production by 2.6 times (from 121 thousand tons in 2004 to 314 thousand tons in 2017). This fact convincingly proves that the processes of concentration and regional specialization in this sector are clear and significant. The data on the growth of localization coefficients of poultry farming regions are shown in Fig. 4.
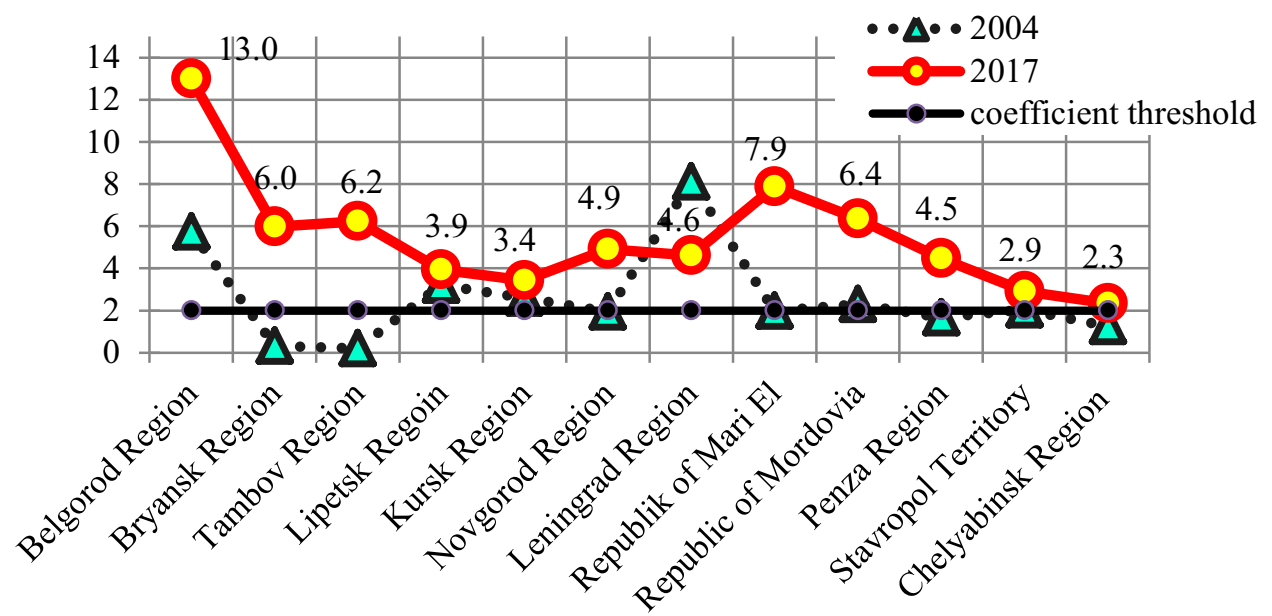

Fig. 4. Localization coefficients: Russian regions with localization coefficients above 2.0 (were calculated according to the indicator "poultry meat (live weight), raised in agricultural organizations", in proportion to the average annual number of employees). Source: compiled by the author based on data from https://fedstat.ru/

\section{Discussion}

The results obtained in the course of the study allowed dividing the regions of Russia into three groups according to the type of strategy in relation to poultry meat farming:

- region's strategy - accelerated development of poultry meat farming. This is a group of regions shown above in Fig. 3. Most of them initially had a high specialization in the poultry meat sector (at the level of 2.0), and over 13 years they have significantly increased its level (Fig. 4). The undisputed leader in this group is Belgorod (the localization coefficient in 2004 was 5.7). For 13 years, the region has increased its production output by more than 10 times, and by 2017, it ranks first in Russia with a production share of $14 \%$ (843 thousand tons). There are also regions that entered this group almost "from scratch" Tambov (growth in poultry meat over 13 years by 124 times) and Bryansk (growth by 70 times);

- region's strategy - preservation and development of poultry meat farming. The group included about 45 regions that did not have a reduction in production during the study period. Moreover, on average for this group, poultry meat production increased by 3.3 times (which corresponds to the overall dynamics in Russia as a whole);

- 14 regions had a reduction in poultry meat production. In the aggregate of these regions, the output of products has decreased by 2 times (over 2004-2017). There are such regions in almost every federal district - the Central Federal District (Kostroma, Ryazan, 
Smolensk), the Northwestern Federal District (Vologda and others), etc. For example, one of the main reasons for the reduction in poultry meat production in the Kirov Region was the shutdown of poultry factories due to the bankruptcy of the regional agricultural holding "KirovKhleb" (the process was completed in 2016).

As a result, it should be emphasized, first, that two-thirds of the growth in the sector's output was provided by 12 regions - the leaders in the poultry meat sector (Table 1). Second, agricultural holdings have become the main growth driver in the sector in that territory. A large share of government subsidies to support agriculture was received by large holdings [1].

Table 1. Poultry meat grown (in live weight): share of highly specialized regions

\begin{tabular}{|c|c|c|c|c|c|}
\hline \multirow[b]{2}{*}{ Farm categories } & \multicolumn{2}{|c|}{2005} & \multicolumn{2}{|c|}{2017} & \multirow{2}{*}{$\begin{array}{l}2017 \\
\% \text { to } \\
2005\end{array}$} \\
\hline & \begin{tabular}{|c|}
$\begin{array}{c}\text { thousand } \\
\text { tons }\end{array}$ \\
\end{tabular} & $\begin{array}{c}\% \text { to the } \\
\text { total }\end{array}$ & $\begin{array}{c}\begin{array}{c}\text { thousand } \\
\text { tons }\end{array} \\
\end{array}$ & $\begin{array}{c}\begin{array}{c}\% \text { to the } \\
\text { total }\end{array} \\
\end{array}$ & \\
\hline $\begin{array}{l}\text { The group of } 12 \text { regions with } \\
\text { localization coefficients over } 2.0 \text {, total }\end{array}$ & 628.4 & 31 & $3,529.2$ & 53 & 562 \\
\hline \multicolumn{6}{|l|}{ including: } \\
\hline agricultural organisations & 548.5 & 27 & $3,461.1$ & 52 & 631 \\
\hline farmers & 0.6 & - & 2.9 & - & 483 \\
\hline households & 79.3 & 4 & 65.2 & 1 & 82 \\
\hline All other regions of Russia, total & $1,366.8$ & 69 & $3,154.3$ & 47 & 231 \\
\hline \multicolumn{6}{|l|}{ including: } \\
\hline agricultural organisations & $1,066.0$ & 53 & $2,735.0$ & 41 & 257 \\
\hline farmers & 10.4 & 1 & 65.7 & 1 & 632 \\
\hline households & 290.4 & 15 & 353.6 & 5 & 122 \\
\hline Grand total in Russia & $1,995.2$ & 100 & $6,683.5$ & 100 & 335 \\
\hline
\end{tabular}

Source: compiled by the author based on data from https://fedstat.ru/

What factors contributed to the location and growth of the poultry meat sector in the regions being the leaders in poultry farming? Obviously, natural and climatic factors did not have a leading influence in this case. Two factors appear to be the core:

- conditions in the region that were created for the development of agribusiness. Thus, the super high concentration of poultry and pig farming in the Belgorod Region is, among other things, the result of the strategy and purposeful work of the regional Government. Such conditions stimulated the entry of large companies into the region;

- the proximity of large food markets had a significant impact on the decisions on the choice of territories for the location of poultry enterprises. Thus, the results of this research confirm the conclusions in [16] that the most large-scale transformations take place in the "semi-peripheral" regions.

In the course of the research, it was revealed that in the poultry industry in Russia there was a significant increase in regional specialization and territorial concentration.

\section{Conclusions}

The study of the processes of regional specialization and territorial concentration taking as a case study the poultry meat sector in Russia allows formulating several main conclusions: - more than half of the production of meat poultry is concentrated in 12 regions of Russia. The largest localization of poultry farming is in the center of the European part of the country, near large cities; 
- the level of territorial concentration of the poultry meat sector for the period of 20042017 increased significantly. The localization coefficients of the regions that specialize in poultry meat production have more than doubled;

- there is an increase in the "polarity" in the specialization of regions using the example of the poultry meat sector. Some regions continue to increase the production of poultry, with a further increase in the level of regional specialization. In other regions, poultry production is declining, entrepreneurs are leaving this business.

Thus, using the example of the meat poultry sector, one can see how the processes of regional specialization and territorial localization are intensifying in Russian agriculture.

\section{Reference}

1. V. Uzun, N. Shagaida, Z. Lerman, Russian agriculture: Growth and institutional $\begin{array}{lllll}\text { challenges, Land Use Policy, } & \text { 83, 2019) }\end{array}$ doi.org/10.1016/j.landusepol.2019.02.018

2. O. Kostenko, Modified localization coefficients for cluster processes identification: a comparative analysis (case study: the Russian rye sector), International Conference on Efficient Production and Processing (ICEPP-2020), E3S Web Conf., 161 (2020) doi.org/10.1051/e3sconf/202016101008

3. E. Carayannis, E. Grigoroudis, Quadruple Innovation Helix and Smart Specialization: Knowledge Production and National Competitiveness, Foresight and STI Governance, 10(1), 31-42 (2016) doi: 10.17323/1995-459x.2016.1.31.42

4. A. Bosch, N. Vonortas, Smart Specialization as a Tool to Foster Innovation in Emerging Economies: Lessons from Brazil, Foresight and STI Governance, 13(1), 32 47 (2019) doi: 10.17323/2500-2597.2019.1.32.47

5. E. Kutsenko, E. Islankina, A. Kindras, Smart by Oneself? An Analysis of Russian Regional Innovation. Strategies within the RIS3 Framework, Foresight and STI Governance, 12(1), 25-45 (2018) doi: 10.17323/2500-2597.2018.1.25.45

6. C. Long, X. Zhang, Patterns of China's industrialization: Concentration, specialization, and clustering, China Economic Review, 23(3), 593-612 (2012) doi.org/10.1016/j.chieco.2011.09.002

7. J. D. Michler, Agriculture in the process of development: A micro-perspective, World Development, 129, Article 104888 (2020) doi.org/10.1016/j.worlddev.2020.104888

8. C. Pachoud, V. Labeyrie, E. Polge, Collective action in Localized Agrifood Systems: An analysis by the social networks and the proximities. Study of a Serrano cheese producers' association in the Campos de Cima da Serra/Brazil, Journal of Rural Studies, 9, 58-74 (2019) doi.org/10.1016/j.jrurstud.2019.10.003

9. C. Lamine, L. Garçon, G. Brunori, Territorial agrifood systems: A Franco-Italian contribution to the debates over alternative food networks in rural areas, Journal of Rural Studies, 68, 159-170 (2019) doi.org/10.1016/j.jrurstud.2018.11.007

10. D. J. Abson, Chapter 19: The Economic Drivers and Consequences of Agricultural Specialization, Agroecosystem Diversity, 301-315 (2019) doi.org/10.1016/B978-0-12811050-8.00019-4

11. T. Kemeny, M. Storper, Is specialization good for regional economic development? Regional Studies, 49(6), 1003-1018 (2015) doi.org/10.1080/00343404.2014.899691

12. S. N. Rastvortseva, D. S. Ternovskii, Driver of concentration of economic activity in Russia's regions, Economic and Social Changes: Facts, Trends, Forecast, 2, 153-170 (2016) doi: 10.15838/esc.2016.2.44.9 
13. I. Grebenkin, Trends in industrial specializations and development dynamics in the Russian regions, Economics of Region, 16, 69-83 (2020) doi.org/10.17059/2020-1-6

14. V. S. Antonyuk, E. R. Vansovich, A. S. Lapo, Transformation in industrial specialization and feature of economic development across the subjects of the Russian Federation, Journal of New Economy, 21(1), 72-88 (2020) doi:10.29141/2658-50812020-21-1-4

15. I. L. Lyubimov, A. G. Ospanova, How to make an economy more complex? The determinants of complexity in historical perspective, Voprosy Ekonomiki, 2, 36-53 (2019) doi.org/10.32609/0042-8736-2019-2-36-53

16. E. Kutsenko, Y. Eferin, "Whirlpools" and "Safe Harbors" in the dynamics of industrial specialization in Russian regions, Foresight and STI Governance, 13(3), 24-40 (2019) doi: 10.17323/2500-2597.2019.3.24.40 